\title{
Spatial heterogeneity in estuarine mud dynamics
}

\author{
Daphne van der Wal · Thijs van Kessel • \\ Marieke A. Eleveld • Joris Vanlede
}

Received: 17 August 2009/Accepted: 28 January 2010/Published online: 5 March 2010

(C) The Author(s) 2010. This article is published with open access at Springerlink.com

\begin{abstract}
The fate of mud in an estuary over an entire year was unravelled using complementary, independent, spatially explicit techniques. Sequential ERS-2 SAR and Envisat MERIS-FR data were used to derive synoptic changes in intertidal bottom mud and suspended particulate matter (SPM) in the top of the water column, respectively. These satellite data were combined with in situ measurements and with a high resolution three-dimensional cohesive sediment model, simulating mud transport, resuspension, settling and deposition under the influence of tides, wind, waves and freshwater discharge. The spatial distribution of both bottom mud and SPM as observed by in situ and satellite techniques was largely explained by modelled estuarine circulation, tidal and wind-induced variations in vertical mixing and horizontal advection. The three data sources also showed similar spring-neap and seasonal variations in
\end{abstract}

Responsible Editor: Han Winterwerp

D. van der Wal $(\bowtie)$

Centre for Estuarine and Marine Ecology,

Netherlands Institute of Ecology (NIOO-KNAW),

P.O. Box 140, 4400 AC Yerseke, The Netherlands

e-mail: d.vanderwal@nioo.knaw.nl

T. van Kessel

Unit Marine and Coastal Systems, Deltares,

P.O. Box 177, 2600 MH Delft, The Netherlands

\section{A. Eleveld}

Institute for Environmental Studies,

Vrije Universiteit Amsterdam (VU-IVM),

De Boelelaan 1085,

1081 HV Amsterdam, The Netherlands

J. Vanlede

Flanders Hydraulics Research, Flemish Government,

Berchemlei 115,

2140 Antwerp, Belgium
SPM (all factor 1.5 to 2), but semi-diurnal tidal variations were underestimated by the model. Satellite data revealed that changes in intertidal bottom mud were spatially heterogeneous, but on average mud content doubled during summer, which was confirmed by in situ data. The model did not show such seasonal variation in bed sediment, suggesting that seasonal dynamics are not well explained by the physical factors presently implemented in the model, but may be largely attributed to other (internal) factors, including increased floc size in summer, temporal stabilisation of the sediment by microphytobenthos and a substantially lower roughness of the intertidal bed in summer as observed by the satellite. The effects of such factors on estuarine mud dynamics were evaluated.

Keywords Satellite remote sensing $\cdot$ Cohesive sediment transport model $\cdot$ Suspended sediment $\cdot$ Intertidal bed sediment · Bed roughness - Water-bed exchange .

Westerschelde

\section{Introduction}

The distribution and transport of mud-here defined as the percentage of particles $<63 \mu \mathrm{m}$, including both clay $(<2 \mu \mathrm{m})$ and silt $(2-63 \mu \mathrm{m})$ - in estuaries has both economical and ecological ramifications. Siltation poses problems in many harbours and navigation channels. As fines attract organic and inorganic substances, their pathways also control the fate of pollutants and nutrients (Verlaan et al. 1998; Ridgway and Shimmield 2002; Schwartz and Kozerski 2004). Muddy bottom sediments of the intertidal zone in particular may be biologically rich, accommodating large amounts of microphytobenthos and macrobenthos, attracting flatfish and (wading) birds (e.g., 
Herman et al. 1999; Moreira 1999). However, when suspended, the mud particles decrease light conditions in the water. This may reduce primary production and subsequently, higher trophic levels (Heip et al. 1995), and may also directly affect sight-feeding predators.

The pathway of estuarine mud is largely determined by estuarine circulation, tidal and wind-induced variations in vertical mixing and horizontal advection (Grabemann and Krause 1989; Ridderinkhof et al. 2000). Suspended particulate matter (SPM) settles when turbulent kinetic energy decreases. Depending on the concentration of SPM, particles may either deposit on the bed or-caused by hindered settling - may form mobile high concentration suspensions near the bed, which eventually become static and continue to settle until they consolidate and form a stable settled mud (Cancino and Neves 1994).

In situ studies have shown that intertidal areas in particular may provide a stock of muddy material, which can undergo cycles of resuspension, settling and deposition on a tidal cycle (Le Hir et al. 2000), on a neap-spring cycle (Allen and Duffy 1998) as well as on a seasonal scale (Anderson 1983; Lesourd et al. 2003; Widdows et al. 2004). Field measurements on intertidal flats also show that the erodibility of cohesive sediments depends on the physical properties of the sediment, such as sediment grain-size and bulk density, and on biological variables, such as stabilisation of the sediment by microphytobenthos. Thus, the (seasonal) cycle of erosion and deposition is re-inforced by the cycle of biological production (Frostick and McCave 1979; Underwood and Paterson 1993; Andersen and Pejrup 2001; Widdows et al. 2004) and biological aggregation and floc formation (Dyer et al. 2000; Chen et al. 2005b; Chang et al. 2007). However, in situ studies generally suffer from restrictions in space and time, causing significant uncertainties when extrapolating the results to a whole estuary.

In contrast, remote sensing provides synoptic information over vast areas. Based on electromagnetic radiation, this information is also independent of in situ data. The spatial distribution of the mud content of intertidal sediments has been derived from optical airborne and satellite remote sensing (e.g., Yates et al. 1993; Rainey et al. 2003; van der Wal and Herman 2007), and microwave satellite remote sensing (van der Wal et al. 2005), but the dynamics of bottom mud have rarely been addressed using remote sensing (van der Wal et al. 2008). Suspended material at the near-surface of the water column in estuaries has been quantified using optical airborne and satellite remote sensing (e.g., Robinson et al. 1998; Uncles et al. 2001), generally based on measurements and subsequent optical modelling of spectral properties of estuarine SPM (Bale et al. 1994; Forget et al. 1999). Availability of moderate and medium resolution ocean colour satellite sensors, such as MODIS or MERIS, has increased the applicability for retrieval of suspended sediments in optically complex waters (i.e., waters that contain uncorrelated light absorbing substances), such as estuaries (e.g., Miller and McKee 2004; Doerffer and Schiller 2007), as well as the feasibility to address the dynamics of SPM with remote sensing (e.g., Doxaran et al. 2009).

High resolution three-dimensional (3D) numerical transport models for cohesive sediment transport can provide insight in the mechanisms of estuarine mud distribution and transport and formalise the relationships between sediment of the bed surface and suspended sediment of the top of the water column as derived from in situ and satellite observations. Such models can also support estuarine management, for example to predict the effects of dredging and dumping of sediment, harbour and fairway extensions, and creation or removal of intertidal areas. However, the models have been typically applied over a spring-neap cycle (e.g., Teisson 1991; Cancino and Neves 1994; Le Normant 2000; Widdows et al. 2004; Waeles et al. 2007), rather than a scale of months or years (Lumborg and Windelin 2003). Simulation of at least 1 year with high temporal and spatial resolution would capture the (semi-) diurnal, fortnightly and seasonal cycles that combine to determine the mud exchange within an estuary.

Thus, we hypothesise that detailed in situ measurements, synoptic satellite observations and numerical modelling are mutually beneficial and provide independent sources for intercomparison and when combined, advance the description and understanding of the spatio-temporal variability of mud. The objective of this study is to quantify the fate of mud in an estuary over a period of an entire year using these three sources of information, with emphasis on the distribution and dynamics of mud that is stored on the intertidal flats.

Results from long-term in situ sediment sampling of both the intertidal sediment bed and the water column and synoptic satellite data of both the intertidal sediment bed and the near-surface water layer are compared with the outcome from a 3D mud transport model that is run in 30 min time-steps for the entire year of 2006 to yield synoptic time series of the mud exchange processes within the Westerschelde, an estuary in the southwestern part of The Netherlands (Fig. 1).

\section{Study site}

The Westerschelde is a typical tide-dominated coastal-plain estuary with representative hydrodynamics, as its tidal amplitude, morphometry and friction characteristics approach the average value for estuaries worldwide (Toffolon et al. 2006). The estuary experiences a semi-diurnal tide; the mean tidal range increases from $3.8 \mathrm{~m}$ near the mouth to $5.0 \mathrm{~m}$ near the Dutch-Belgian border. The tidal prism is 
Fig. 1 Location of the Westerschelde (The Netherlands) and Zeeschelde (Belgium) with distance (in $\mathrm{km}$ ) from the mouth at Vlissingen. Darker tones in the Westerschelde show deeper areas. In situ SPM monitoring stations $(V L I=$ Vlissingen, $T E R=$ Terneuzen, $H A N=$ Hansweert, $\mathrm{SCH}=$ Schaar van Ouden Doel) are indicated as black dots, in situ bed sediment monitoring stations are indicated as open circles

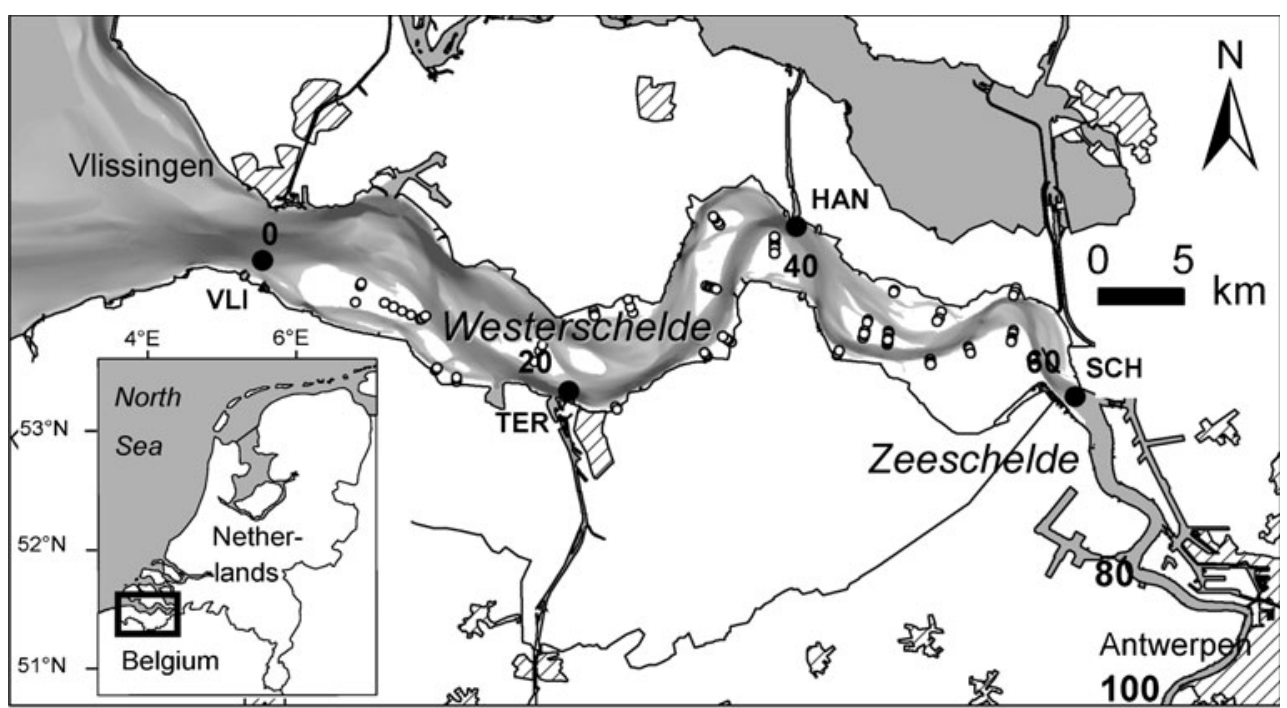

about $2 \times 10^{9} \mathrm{~m}^{3}$ (Wang et al. 2002). Tidal discharge at the mouth is on average $50,000 \mathrm{~m}^{3} \mathrm{~s}^{-1}$ (Chen et al. 2005a), whereas river discharge varies from ca. $20 \mathrm{~m}^{3} \mathrm{~s}^{-1}$ in summer to $180 \mathrm{~m}^{3} \mathrm{~s}^{-1}$ in winter (Baeyens et al. 1998). The Westerschelde is well-mixed up to ca. $40 \mathrm{~km}$ from the mouth, and partially mixed beyond this zone. The estuarine turbidity maximum (ETM) is situated in the Zeeschelde (i.e., the upstream part of the Scheldt estuary, situated in Belgium), ca. 60 to $100 \mathrm{~km}$ from the mouth of the Westerschelde, depending on tidal conditions and river discharge (Chen et al. 2005a). In addition, a turbidity maximum is found along the North Sea coast south of the Westerschelde (Vlaamse Banken; Fettweis and van den Eynde 2003). The proportion of marine bed sediment relative to fluvial sediment gradually changes from $95 \%$ at the mouth of the Westerschelde to $75 \%$ near the DutchBelgian border, and then drops drastically to $10 \%$ in the upper reaches of the estuary (Verlaan 2000). Sediment of the Westerschelde has a constant clay to silt ratio of ca. 0.25 (Winterwerp and van Kesteren 2004). Low water exposes sandflats and mudflats along the sides of the estuary (labelled 'fringing flats'), as well as sandbank and mudbank islands in mid-channel ('mid-channel flats'). These intertidal areas are unvegetated, with the exception of a number of saltmarsh areas on the higher parts.

\section{Materials and methods}

\subsection{In situ measurements of bed sediment}

A large dataset (MOVE database, Rijkswaterstaat 2006) provided the source of independent in situ data of the bed. Bed sediment was surveyed every 1-3 months in the period 1995-2007 at 95 intertidal (i.e., located above -1 m NAP (Dutch Ordnance Datum)) monitoring stations (Fig. 1).
Surveys from August had to be discarded as these were biased by undersampling. The remaining dataset (with number of observations $n=5,196$ ) included estimates of the clay content of the surface sediment and (for a subset) measurements of the depth of the mud layer. The relative elevation of the bed was monitored with a triangle-shaped sedimentation-erosion bar, fixed with steel rods, averaging five readings at each side of the triangle at $20 \mathrm{~cm}$ intervals for each measurement. The measurements were related to absolute elevation once for each station using a DGPS.

A second dataset (GeoSeas McLaren data, Storm and van Maldegem 1997) contained samples collected in August/September 1993 from the upper 5 to $10 \mathrm{~cm}$ of the bed of the intertidal zone in a $500 \times 500 \mathrm{~m}$ grid. Mud content of the samples $(n=134)$ was determined using a Malvern 2600 laser particle sizer. This dataset was used for calibration of the remote sensing data.

A third dataset (NIOO-KNAW data) was used for an independent validation. The upper $5 \mathrm{~cm}$ of sediment was sampled at the intertidal monitoring stations (Fig. 1) in the period 10-21 April 2006. Samples $(n=95)$ were freezedried and the mud content was determined using a Malvern Mastersizer 2000 laser particle sizer, without prior removal of organic matter and carbonates. Values of mud content obtained by the Malvern Mastersizer 2000 were transformed following the procedure given in van der Wal et al. (2005) to allow for a better comparison with the results from the Malvern 2600 laser particle sizer.

\subsection{In situ measurements of SPM}

SPM was measured in situ on four stations in the Westerschelde (Fig. 1), at a depth of ca. $1 \mathrm{~m}$ below the water surface (MWTL database, Rijkswaterstaat 2009), providing an independent data source. Samples collected in the period 1995-2007 were selected for further analysis 
$(n=1,356)$; these were taken randomly across the tidal phase, but not during storms. The associated tidal stage for each measurement and site was calculated using time series of predicted tidal harmonics at Oostende (MUMM 2009). One outlier (SPM $>1,200 \mathrm{mg} \mathrm{l}^{-1}$, station TER) was removed (this outlier may have been caused by the release of dredged material in this area).

\subsection{Remote sensing of bed sediment}

On intertidal areas, satellite C-band SAR mainly gives information on the roughness of the (sediment) surface (van der Wal et al. 2005). Since bed roughness is generally related to the sediment characteristics (with surface ripples being lower or absent in mud), mud content can be also derived from SAR backscatter (van der Wal et al. 2005; van der Wal and Herman 2007). For this paper, SAR (C-band, VV polarisation) precision images were obtained from the ESA satellite ERS-2. The images have a nominal resolution of ca. $30 \mathrm{~m}$, and a pixel size of $12.5 \mathrm{~m}$, and revisiting time of the satellite is 35 days. A selection is made of all archived SAR images from 2006 that (1) cover either the whole or the eastern part of the Westerschelde, (2) are acquired when water levels in the Westerschelde were below $-1 \mathrm{~m}$ NAP and (3) are acquired at ca 10:40 UTC, i.e., descending mode of the satellite. This yielded nine ERS-2 SAR images of 2006. In addition, images of 3 October 1993, 7 April 2003, 29 September 2003 and 7 April 2004 were used. From the selected SAR data, brightness values $\beta^{0}$, normalised to the mid-swath incidence angle of $23^{\circ}$, were calculated (Laur et al. 2002), and a moving average of $9 \times 9$ pixels was applied to improve radiometric resolution. The images were rectified and transformed to the Dutch National Grid, applying a cubic convolution interpolation technique. A mask was applied to exclude (1) areas below -1 m NAP taken from a bathymetric survey, (2) vegetated areas as detected using a Landsat ETM+ image of 1 July 2006 and (3) groynes, embankments and areas outside the Westerschelde.

A dataset of bed roughness $s$ (expressed as the rootmean-square of surface height in $\mathrm{cm}$ ) measured in situ on four intertidal flats during acquisition of the SAR imagery of 2003 and 2004 (van der Wal et al. 2005) was used to calibrate the bed roughness retrieval algorithm. Values of $s$ collected at sites without surface water were related to the brightness intensities $\beta^{0}$ from the matching SAR images in a non-linear least-squares regression with LevenbergMarquard estimation (leaving out two outliers with residuals exceeding $2 \sigma ; R^{2}=0.84, n=29, P<0.00001$ ), yielding:

$s=0.52\left(\beta^{0}\right)^{0.60}$

This equation complies with backscatter theory (Fung et al. 1992), as elaborated in van der Wal et al. (2005). A maximum of $s=0.6 \mathrm{~cm}$ is set because larger values of $s$ cannot be retrieved unambiguously from the backscatter values under typical conditions in the intertidal areas (van der Wal et al. 2005). The retrieval algorithm was then applied to the SAR images of 2006 to yield maps of $s$.

The in situ mud content data of August/September 1993 (GeoSeas McLaren data) were related to the brightness values from the matching SAR image in a GIS following procedures outlined in van der Wal and Herman (2007), to obtain a robust regression equation $\left(R^{2}=0.55, n=134, \mathrm{SE}=\right.$ $0.813, P<0.00001)$ :

$\ln (M+1)=-0.212 \beta_{\mathrm{db}}^{0}+0.930$

in which $M$ is the percentage of mud of the sediment, and $\beta_{\mathrm{db}}{ }^{0}$ is the brightness value (in $\mathrm{dB}$ ). This algorithm was applied to the SAR images of 2006 to yield maps of $M$. A coefficient of variation has been calculated from the remote sensing derived maps of mud content covering the entire Westerschelde (i.e., the maps of 14 January, 1 May, 14 August and 27 November 2006), to gain further insight in the dynamics of the distribution of mud over the year. The Westerschelde was also subdivided in separate intertidal flats, and the mean mud content for each tidal flat was calculated for each image. Finally, the remote sensing derived data were validated using sediment data collected in the field in 2006 (MOVE and NIOO-KNAW datasets).

\subsection{Remote sensing of near-surface SPM}

Characteristics of the top of the water column were obtained from remote sensing using time series of MERIS data. MERIS is a multispectral sensor on board ESA's Envisat satellite and captures images in several narrow optical and near-infrared bands with a ground resolution of ca. $300 \mathrm{~m}$ (Full Resolution), yielding two images per 3 days for this region. All images of 2006 that contained no or little clouds were processed with HYDROPT. Although various suitable MERIS coastal water algorithms are available (Moore et al. 1999; Doerffer and Schiller 2007, Schroeder et al. 2007), HYDROPT (van der Woerd and Pasterkamp 2008) allowed input of inherent optical properties (IOPs) of the Westerschelde. HYDROPT comprises of a forward model that generates water-leaving radiance reflectance $\left(\rho_{\mathrm{w}}\right)$ as a function of among others the IOPs absorption (a) and scattering (b) of North Sea water and its constituents chlorophyll (CHL), SPM and coloured dissolved organic matter (CDOM). It is based on radiative transfer modelling with Hydrolight (Mobley and Sundman 2001) and for this study parameterized with mass specific IOPs (sIOPs, i.e., absorption and scattering coefficients normalised to concentrations) taken from three earlier cruises carried out in the Westerschelde (Belgica 2000) 
and adjacent North Sea (Restwes 1999 and Oroma 2002), after optical modelling and comparison with concurrently collected in situ spectra for quality control. The inverse model estimates the concentrations of the constituents from MERIS $\rho_{\mathrm{w}}$ at several optical wavelength intervals using Levenberg-Marquard optimization. For this, MERIS bands 2 to 7 and 9 were used (band 1 was discarded due to its sensitivity to errors in atmospheric correction and band 8 was discarded because of a possible contribution of fluorescence to the reflectance signal). The inversion comprises $\chi^{2}$ fitting of the modelled to measured $\rho_{\mathrm{w}}$ and also renders standard errors with the retrieved CHL, SPM and CDOM concentrations. In addition, probabilities were derived from the cumulative distribution function for the $\chi^{2}$, and ESA's Level 2 Product Confidence Data (PCD) flags (ESA 2006) were passed on. The compound confidence flag PCD_1_13 provided by ESA-indicating for example negative reflectances as a result of overcorrection for aerosol scattering, uncorrectable sunglint and whitecapping - was also assumed to comprise adjacency effects (Santer and Schmechtig 2000) and was used to identify unreliable values for water. The data were verified using in situ SPM match-ups collected in 2006. As with in situ data, the associated tidal conditions were added to the remote sensing derived SPM data for further analysis.

\subsection{Modelling of bed sediment and SPM}

The cohesive sediment transport model of the Westerschelde (van Kessel et al. 2006) is based on the Delft3D modelling suite (Stelling and van Kester 1994) and applies an advection-dispersion equation (e.g., Teisson 1991) using 3D current velocity components and water levels simulated for 2006 at $30 \mathrm{~min}$ intervals (equalling 1 month of computing time) by a (decoupled) hydrodynamic model set up in TRIWAQ/SIMONA. Spatial resolution of the hydrodynamic model varies from $400 \mathrm{~m}$ in the far field (North Sea) to $150 \mathrm{~m}$ in the Westerschelde and $30 \mathrm{~m}$ in the Zeeschelde, whereas for the mud transport model a $2 \times 2$ cells aggregation is used to reduce computing time. The horizontal grid used in the hydrodynamical simulations has five logarithmically distributed sigma layers in the vertical, with the finest layer closest to the bed. A variable hydraulic roughness has been implemented, with Manning coefficients varying from $0.024 \mathrm{~m}^{-1 / 3} \mathrm{~s}$ at the mouth to $0.028 \mathrm{~m}^{-1 / 3} \mathrm{~s}$ at the Dutch-Belgian border, and decreasing again further upstream, and a corresponding Chézy value is calculated from these coefficients and the water depths at each time-step. In the mud transport model, bed shear stress is recomputed from a uniform Manning coefficient. This is done to include skin friction only as driving factor for resuspension. Form drag introduced to parameterize subgrid bed level variations is thus excluded. Wind forcing is incorporated in the hydrodynamic model using formulations by Smith and Banke (1975) to relate wind velocity (station Vlissingen, Royal Netherlands Meteorological Institute 2009) to interfacial shear stress. Wave effects are implemented in the mud model based on a SWAN wave model (Booij et al. 1999) forced by these wind conditions and observed wave conditions in the North Sea. At the upestuary boundary, freshwater enters the hydrodynamic model via user-defined discharge points. The release of dredged material is accounted for in the mud transport model, either (1) by specifying the release rate in the model input or (2) by specifying a dredged area which is maintained at a specific depth by removal of sediment, which is subsequently released at a user-defined location. The latter method guarantees an exact balance between dredging and dumping.

The bed is represented by two layers, a thin fluffy fine sediment layer (layer 1) deposited during slack water and a 5-cm thick, passive (i.e., no bed level changes) sand bed with a variable mud fraction (layer 2). The erosion flux $F_{\mathrm{e} 1}$ from the fluffy mud layer is calculated from a critical shear stress $\tau_{\text {crit } 1}$ (here $\tau_{c r i t 1}=0.1 \mathrm{~Pa}$ ) and (first and zeroth order) resuspension parameters (here $M_{1}=2.3 \times 10^{-5} \mathrm{~s}^{-1}$ and $M_{0}=$ $\left.m_{0 \rightarrow 1} M_{1}\right)$ :

$F_{\mathrm{e} 1}=\min \left(M_{0}, m M_{1}\right) \times \max \left(0,\left(\tau / \tau_{\text {crit1 }}-1\right)\right)$

where $m$ is the eroded mass per unit area from this layer and $m_{0 \rightarrow 1}$ the mass per unit area at the transition between first and zeroth order erosion (van Kessel et al. 2006). Transition occurs if sufficient material is available to form a uniform mud layer instead of mud patches on a sandy bed, typically at a few kilograms per square metre. The erosion flux $F_{\mathrm{e} 2}$ of fine sediment from the sand bed is based on the pick-up function by van Rijn (1984):

$F_{\mathrm{e} 2}=333 M_{2} p\left(\tau / \tau_{c r i t 2}-1\right)^{1.5}$

where $p$ is the mud fraction in the sand bed (and here $M_{2}=$ $3.5 \times 10^{-7} \mathrm{~kg} \mathrm{~m}^{-2} \mathrm{~s}^{-1}$ and $\tau_{\text {crit } 2}=0.05 \mathrm{~Pa}$ ). The deposition flux to the fluff layer $F_{d 1}$ is calculated by:

$F_{\mathrm{d} 1}=(1-\alpha) w_{\mathrm{s}} C$

and sedimentation to the sand bed $F_{\mathrm{d} 2}$ is calculated by:

$F_{\mathrm{d} 2}=\alpha w_{\mathrm{s}} C$

where $w_{\mathrm{s}}$ is the settling velocity (here $w_{\mathrm{s}}=1 \mathrm{~mm} \mathrm{~s}^{-1}$ for $70 \%$ of the sediment and $w_{\mathrm{s}}=0.2 \mathrm{~mm} \mathrm{~s}^{-1}$ for $30 \%$ of the sediment) and $\alpha$ is the fraction of the flux settling towards layer 2 (here $\alpha=0.1$ for a marine mud fraction and $\alpha=0.05$ for the fluvial mud fraction in the water column; van Kessel et al. 2006). During calm weather, when there is no resuspension from layer 2, mass is gradually transferred from layer 1, where resuspension is still possible, via the 
water column towards layer 2 to account for consolidation. The initial bed composition in the model is derived from the GeoSeas McLaren dataset. However, as the model spinup time is several years, an equilibrium bed composition is reached that is independent of the initial condition. Thus, the model produces information on the distribution of the inorganic mud content of the sediment bed and concentrations of inorganic suspended matter in the water column in space and time.

Compared to a 'classical' single bed layer model with Partheniades-Krone formulations for erosion and deposition, the applied model has three essential advantages: (1) a gradual, instead of a stepwise, transition is obtained between sea bed zones abundant in mud and zones depleted of mud, (2) a dynamic equilibrium bed composition is established for any combination of sediment supply and bed shear stress climate, apart from low-dynamic zones where permanent and ongoing deposition occurs and (3) by changing the second bed layer thickness, the sediment residence time in the bed can be set independently from parameters steering the short-term vertical exchange (so that long-term model behaviour such as the travel time of sediment pulses or attached contaminants can be calibrated using field data). These advantages are unimportant in a completely muddy environment, but have a higher degree of realism for a mixed sand-mud environment. See van Kessel et al. (2006) for further discussion.

\section{Results}

4.1 Bed sediment from in situ measurements, remote sensing and modelling

The independent in situ data (MOVE dataset) reveal a seasonal cycle in clay content, with values ca. 1.5 times (fringing tidal flats) to two times (mid-channel flats) higher in July-September than in January (Fig. 2a). The average thickness of the mud layer also shows a seasonal cycle ranging from $1 \mathrm{~cm}$ in March to $3 \mathrm{~cm}$ in July; thus, a layer of $2 \mathrm{~cm}$ mud is built up over the summer, but ranging from $0.5 \mathrm{~cm}$ on mid-channel flats to $2.5 \mathrm{~cm}$ on fringing flats (Fig. 2b). The seasonality in clay content and mud thickness is not reflected in bed elevation: trends in absolute elevation over the year are generally not significant, suggesting that there is no seasonal variation in the rate of net morphological change (Fig. 2c) and suggesting that non-cohesive sediments determine morphology. Longterm (inter-annual) trends in elevation are, however, apparent at most intertidal stations (not shown).

Satellite data reveal a large spatial heterogeneity in sediment surface mud content (Fig. 3). Remarkably, only part of each tidal flat experiences seasonal changes in surface mud content, whereas other parts stay sandy or muddy throughout the year (Fig. 3e). However, on average mid-channel tidal flats are sandier than the fringing tidal flats, and mud content is lowest in winter (ca. 10\%), and highest in summer (ca. 20\%; Fig. 4b), in accordance with averages derived from the independent in situ data (Fig. 2a, b). Satellite derived bed roughness shows similar spatial and temporal variation, i.e., rougher beds for mid-channel flats than for fringing flats and rougher beds in winter than in summer (e.g., Fig. 4a).

The model roughly reproduces the observed spatial patterns in bed composition, i.e., a lower mud content at exposed (mid-channel) flats and a higher mud content at sheltered (fringing) flats (Fig. 5 versus Fig. 3), showing that the processes included in the model, including estuarine circulation and horizontal advection, largely explain these patterns. The model also stresses the importance of harbours and saltmarsh areas as sinks for mud (see for example high mud contents modelled for the large saltmarsh area in the southeast of the Westerschelde). In contrast to in situ (Fig. 2a) and satellite data (Fig. 3 and 4b), the mud model does not show seasonal dynamics in bed composition on intertidal areas; modelled mud content in
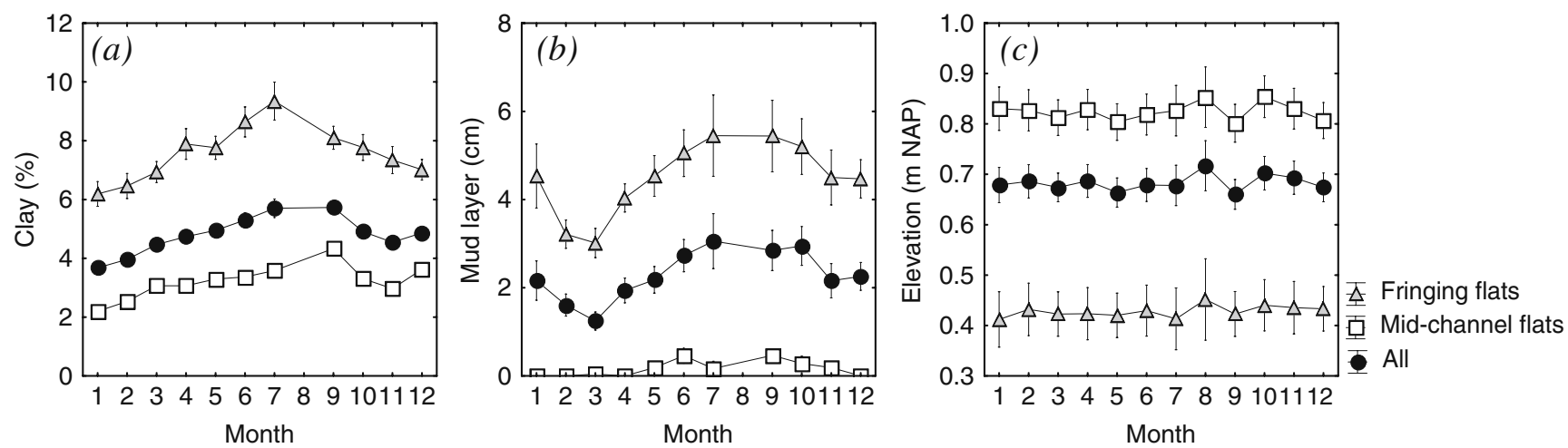

Fig. 2 Average $( \pm \mathrm{SE})$ a clay content, $\mathbf{b}$ thickness of the mud layer and $\mathbf{c}$ elevation of fringing tidal flats and mid-channel tidal flats, from in situ measurements, binned per month, showing a significantly higher clay content and thicker mud layer in summer 
Fig. 3 Maps of mud content of the sediment derived from ESA ERS-2 SAR images of 2006, showing spatial heterogeneity in mud dynamics. Lower panel shows the coefficient of variation, as measure for dynamics in mud content in 2006 , with 0 indicating invariable mud content and 1 indicating variable mud content over the year (a)

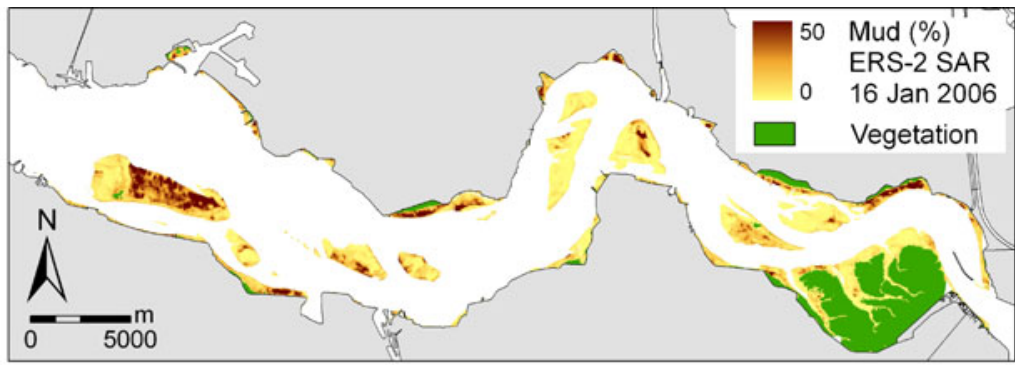

(b)

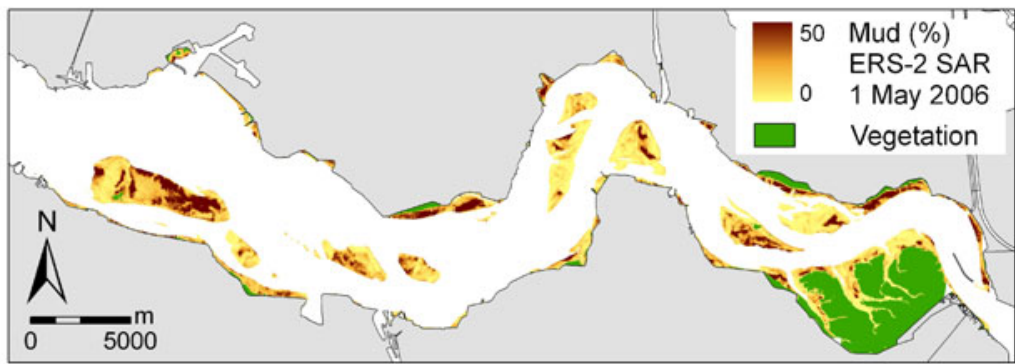

(c)

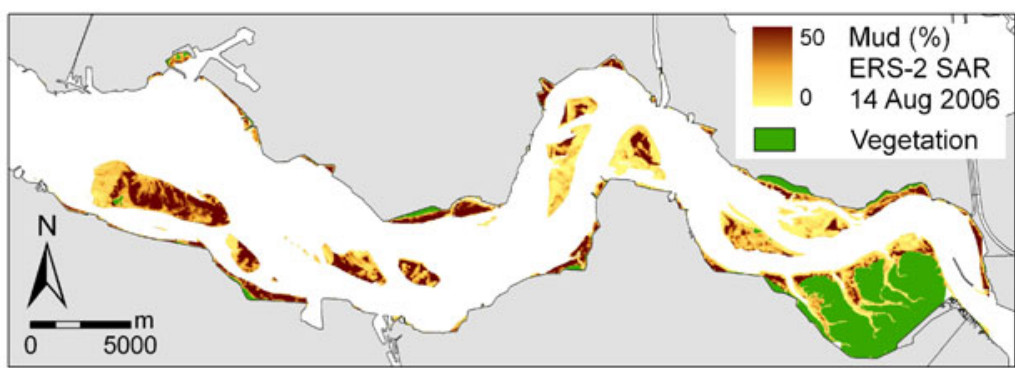

(d)

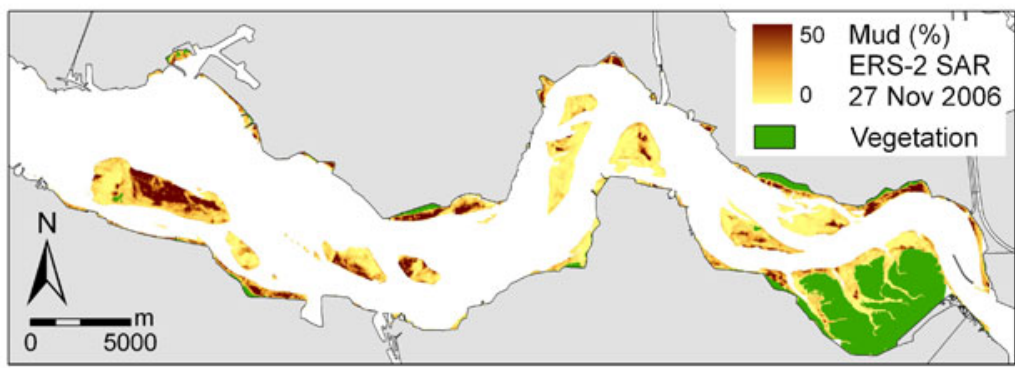

(e)

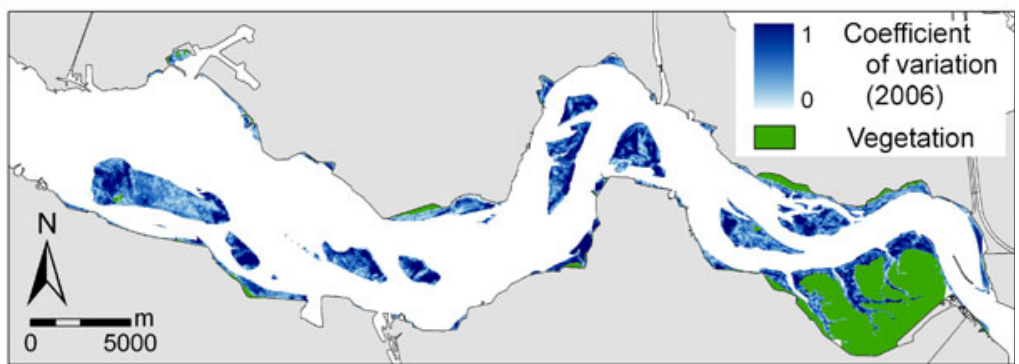

summer is not significantly higher than in winter. In the main channel, low SPM levels in summer even result in a lower modelled mud fraction in the channel bed in summer.

In situ, satellite and model data are significantly correlated for individual intertidal flats in 2006, demonstrating the consistency of the three independent data sources (Fig. 6). In situ clay data from the MOVE dataset and in situ mud data from the NIOO-KNAW dataset confirm that the ratio of the in situ content of clay: mud is constant (i.e., ca. 0.5, Fig. 6a), albeit higher than the ratio reported by Winterwerp and van Kesteren (2004). Satellite data are significantly correlated with in situ clay content and in situ mud content, although SAR-derived mud content is a factor 1.2 higher than in situ mud data (Fig. 6b). Surface mud content derived from remote sensing is also significantly correlated with modelled mud content (Fig. 6c). 
Fig. 4 Average a bed roughness and $\mathbf{b}$ mud content of the sediment derived from ESA ERS-2 SAR images of 2006, showing lowest roughness and highest mud content in summer
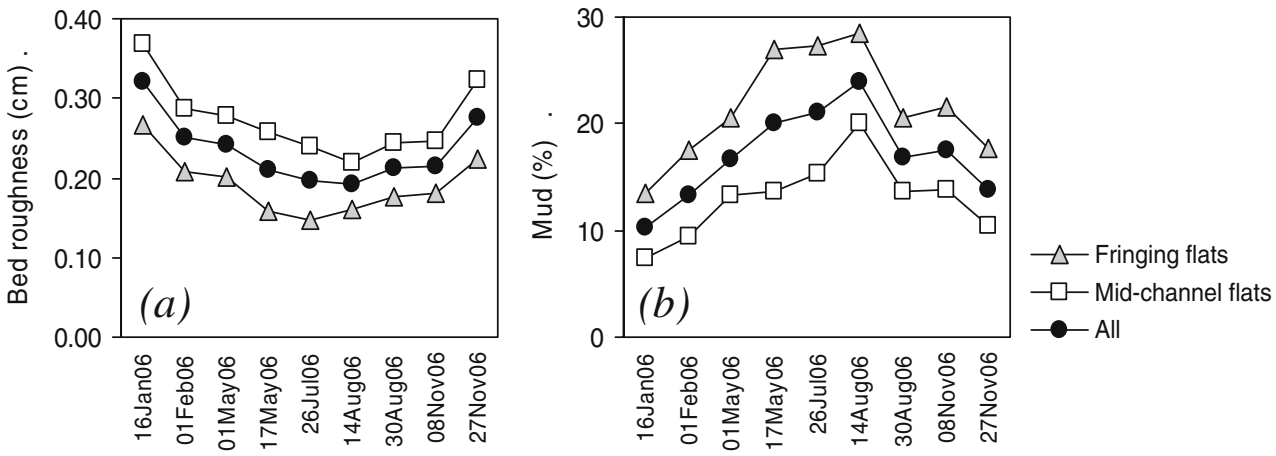

4.2 SPM from in situ measurements, remote sensing and modelling

In situ SPM concentrations at ca. $1 \mathrm{~m}$ depth over the period 1995-2007 (Fig. 7) on the four stations are ca. twice as high in winter (i.e., on average $67 \pm 2 \mathrm{mg} \mathrm{l}^{-1}$ ) than in summer (i.e., on average $39 \pm 2 \mathrm{mg} \mathrm{l}^{-1}$ ), but the seasonal signal ranges from a factor 2-2.5 for station VLI and TER to a factor 1.5 for station HAN and SCH (Fig. 7a). SPM concentrations are low on neaps (on average $31 \pm 3 \mathrm{mg} \mathrm{l}^{-1}$ ) and high on springs $\left(64 \pm 2 \mathrm{mg} \mathrm{l}^{-1}\right)$, i.e., a factor 2 (Fig. $7 \mathrm{~b}$ ). Highest SPM levels are generally found during low water (Fig. 7c) and variation over the semi-diurnal tidal cycle is a factor 1.5 .

The general patterns of variation in satellite-derived SPM concentrations over the semi-diurnal and fortnightly tidal cycle of 2006 at the four stations (Fig. 8) are similar to those obtained from the independent long-term (19952007) in situ data (Fig. 7). Note that the satellite is sunsynchronous, causing low water image acquisitions to uniquely coincide with springs and high water acquisitions with neaps (Fig. 8). The variation in SPM over the neapspring tidal cycle is a factor 2.3. Seasonal variation could not be determined properly, as very little winter images are available.

The modelled seasonal and spring-neap variation in SPM is ca. a factor $1.5\left(45 \mathrm{mg} \mathrm{l}^{-1}\right.$ in summer versus $60 \mathrm{mg} \mathrm{l}^{-1}$ in winter and $46 \mathrm{mg}^{-1}$ on neaps and $60 \mathrm{mg} \mathrm{l}^{-1}$ on springs, respectively; Fig. 9). Changes in modelled SPM over the semi-diurnal tidal cycle follow the same trend as the in situ data (with, for example, highest values of SPM near low water), but the variation in SPM over the semi-diurnal tidal cycle is only pronounced at station $\mathrm{SCH}$ (on average factor 1.1 for all stations).

Average SPM concentrations derived from in situ measurements of the period 1995-2007, satellite observations of 2006 and model results from 2006 are generally comparable for most stations. However, in situ SPM concentrations are lowest at station HAN in the middle part of the estuary, whereas the satellite and model data show lowest values at station VLI in the outer estuary. Best agreement is obtained for the very turbid station $\mathrm{SCH}$ in the upper estuary, i.e., on average $61.05 \pm 1.83 \mathrm{mg} \mathrm{l}^{-1}$ for in situ measurements, $66.47 \pm 6.97 \mathrm{mg} \mathrm{l}^{-1}$ for satellite observations and $75.33 \pm 0.25$ for model simulations.

Maps of remote sensing derived near-surface SPM have been compared with model output of SPM of the top of the water column (Fig. 10). Note that emerged (intertidal) areas are correctly flagged as land in the remote sensing derived maps, but not in the model output, as a minimum water depth is required in the hydrodynamic model (but a certain water depth is needed in the mud transport model before deposition occurs). The general level of turbidity is similar for satellite observations and model results for each 'snapshot': lowest levels of SPM are found on neaps (Fig. 10c) and highest levels on springs (Fig. 10a, b), but depending on tidal stage (highest near low water, see Fig. 10b). Both satellite- and model-derived maps also show a similar pattern of low SPM levels in the channels of the Westerschelde, high SPM levels in the ETM of the
Fig. 5 Modelled mud fraction of the bed sediment, averaged over 2006, showing high mud contents in especially the fringing intertidal areas and harbours. Outline of the intertidal zone is also shown

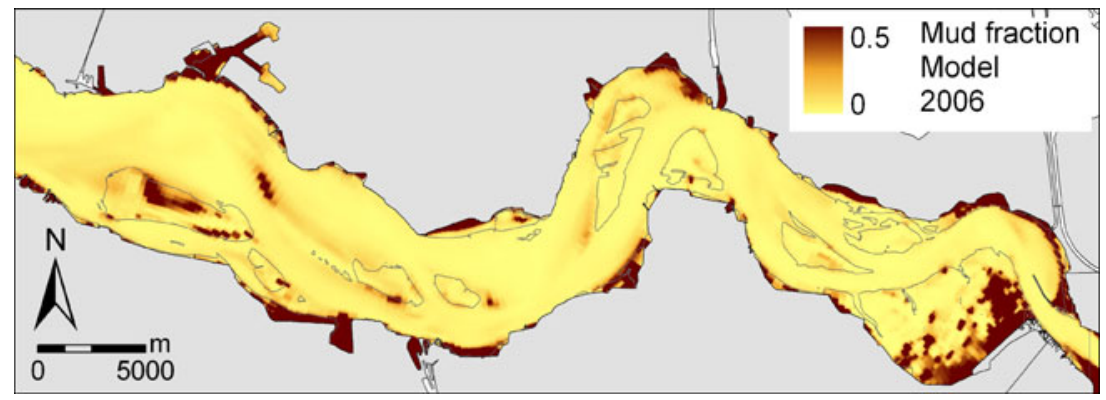



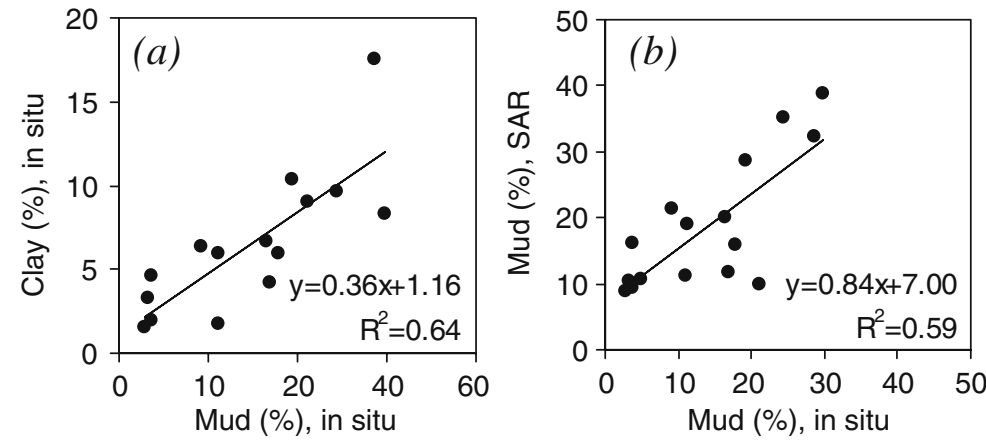

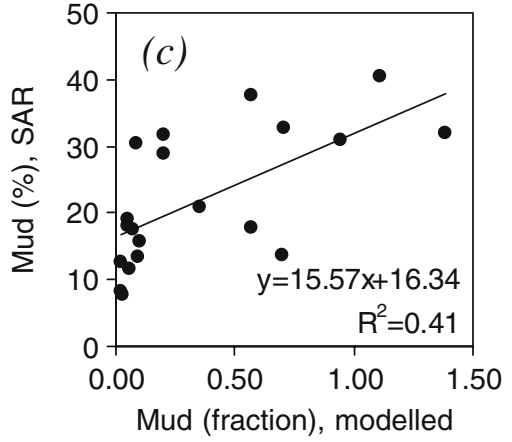

Fig. 6 a In situ clay content (16-23 May 2006) versus in situ mud content (10-21 April 2006) of the bed, b mud content from remote sensing (1 May 2006) versus in situ mud content (10-21 April 2006) and c average annual mud content from remote sensing versus modelled mud content, all averaged per tidal flat

entirely covered by satellite observations. Nevertheless, in situ measurements and observations of clay and mud correlated significantly with observations derived from satellite remote sensing. Together, they allow a good estimate of intra-annual mud dynamics. Synoptic remote sensing data of tidal flats demonstrate that average mud contents of the bottom sediment are ca. twice as high in summer as in winter. However, satellite observations do not provide information on the thickness of this layer. In situ data derived from a long-term time-series confirm the seasonality in mud content and show that a mud layer of on average $2 \mathrm{~cm}$ is building up over summer, at least at the sampled stations. The thickness of this mud layer is lower than independent results from most field studies on intertidal flats, both on a tidal flat in the Westerschelde, where a seasonal build-up of fine material in the top 3-10 $\mathrm{cm}$ of the sediment was found (Herman et al. 2001; Widdows et al. 2004) and elsewhere (e.g., Andersen et al. 2000; Dyer et al. 2000; Lesourd et al. 2003), although thinner layers have also been reported (Chang et al. 2007). The discrepancy can be explained by the fact that spatial variation at the estuary scale is taken into account in our estimate, as large areas show little or no seasonal variation in mud content. sampled in situ at a few sites only, whereas the areas were
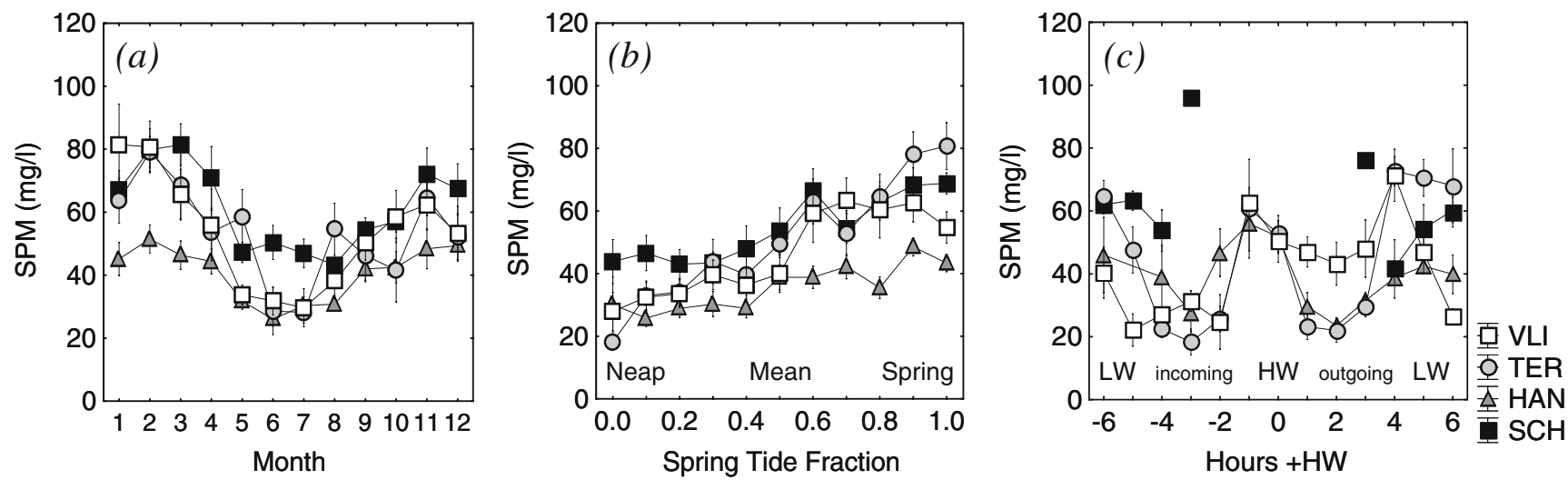

Fig. 7 Average $( \pm \mathrm{SE})$ in situ SPM on four stations at different time-scales, i.e., variation over a a year, $\mathbf{b}$ a neap-spring cycle and $\mathbf{c}$ a semi-diurnal tidal cycle 


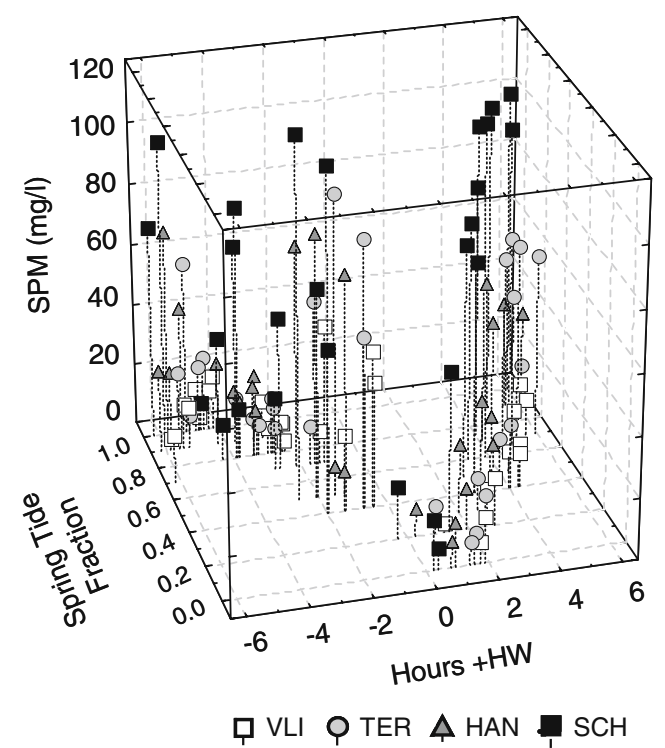

Fig. 8 Sun-synchronous satellite derived near-surface SPM of 2006 on four stations depending on both spring-neap cycle (expressed as spring-tide fraction, with 0 as neap-tide and $l$ as spring-tide) and semidiurnal tidal cycle (expressed as hours after high water)

A very crude estimate of the seasonal variation in surface mud content over the entire intertidal zone (here $89 \times 10^{6} \mathrm{~m}^{2}$ of both unvegetated and saltmarsh areas) can be derived from the combined results of this study. Suppose the volumetric mud content in an active layer of $2 \mathrm{~cm}$ increases from $10 \%$ in winter to $20 \%$ in summer, then ca. $180 \times 10^{3} \mathrm{~m}^{3}$ mud is stored extra in this layer in summer, equalling $180 \mathrm{kton}$ when assuming a dry bulk density of $1,000 \mathrm{~kg} \mathrm{~m}^{-3}$. This amount would double when, alternatively, a 2-cm-thick layer containing $20 \%$ mud is assumed to be deposited on top of the winter bed in summer. Note that even small changes in mud content and mud layer thickness could change the amount considerably. In this case, it is assumed that the saltmarsh areas (totalling $25 \times 10^{6} \mathrm{~m}^{2}$ ) experience a similar seasonal deposition as the unvegetated areas. However, saltmarsh areas may experience a different sedimentation regime (e.g., Temmerman et al. 2004) and saltmarsh sediments generally have a higher mud content (as confirmed by our model results) and higher bulk density.

In parallel to seasonal changes in mud content, seasonality in bed level of the order of a few centimetres have been reported for a number of intertidal flats worldwide, generally with rapid erosion in winter and deposition in spring to autumn (Frostick and McCave 1979; O'Brien et al. 2000; Andersen and Pejrup 2001). Our in situ measurements show that the average rate of morphological change does not change within a year: there is no seasonal effect in net erosion and deposition. Dynamics in the deposition and erosion of sand, rather than mud, may well be determining changes in bed level over a year (and, indeed, also on longer time-scales) and the magnitude of the total annual sediment budget of the Westerschelde estuary.

In situ SPM, satellite-derived SPM and modelled total inorganic matter in the top of the water column have been compared. Here, in situ data relate to ca. $1 \mathrm{~m}$ below the water surface, the satellite data represent the upper surface layer, depending on turbidity, and the model data relate to an upper layer thickness of $41 \%$ of the total water depth. In situ SPM samples were taken from a long-time series, whereas the model and satellite data relate only to 2006 . Moreover, in situ SPM samples taken ca. every 2 weeks and ca. 31 'snapshots' acquired by the satellite will not describe the full variance in SPM. In particular, a bias is introduced because no in situ samples were taken during storm. Satellite observations suffer from a similar bias, as storms may coincide with cloudy weather (also leading to an underrepresentation of winter observations) in addition to a bias induced by the timing of satellite overpass in relation to tidal conditions. With these considerations in mind, the three data sources allow an assessment of SPM dynamics in the Westerschelde estuary.

In situ data show that SPM levels in the Westerschelde are ca. a factor 1.5 to 2 higher in winter than in summer, confirming earlier findings in the adjacent North Sea
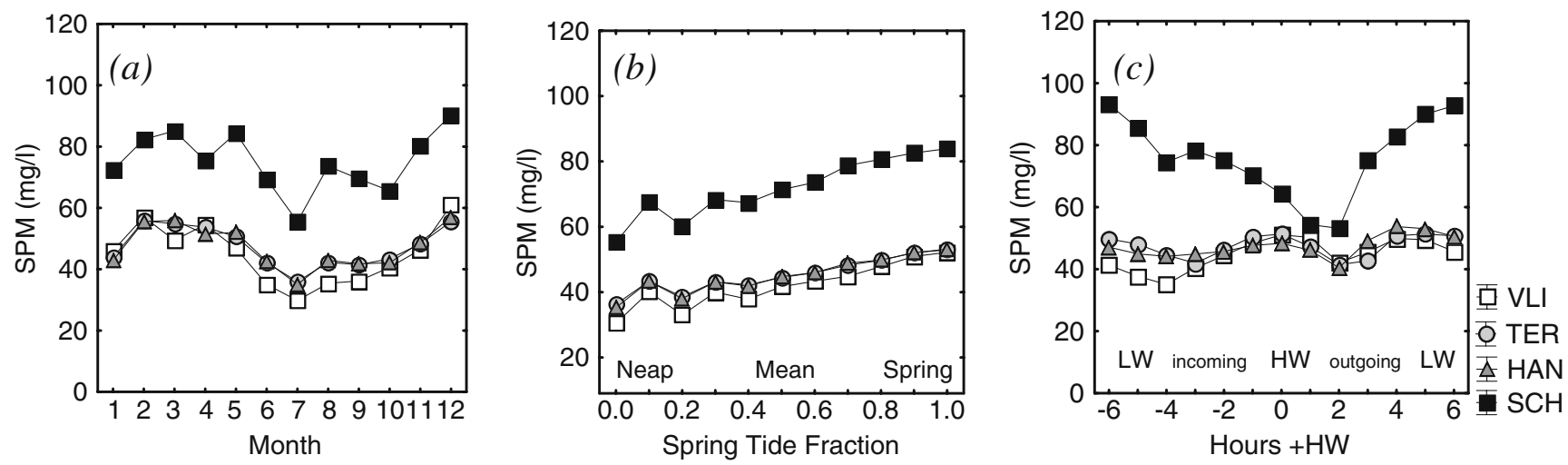

Fig. 9 Average $( \pm$ SE) modelled inorganic SPM of 2006 on four stations at different time-scales, i.e., variation over a a year, b a neap-spring cycle and $\mathbf{c}$ a semi-diurnal tidal cycle 
Fig. 10 Three snapshots of near-surface SPM distribution: a 11 June 2006, b 16 July 2006 and c 16 October 2006, all ca. 10:30 UTC. Upper panel of each snapshot shows total suspended matter (SPM) derived from remote sensing and lower panel of each day shows modelled total inorganic suspended matter at the water surface. Note that emerged (intertidal) areas are masked in the remote sensing derived maps, but not in the model output (a)
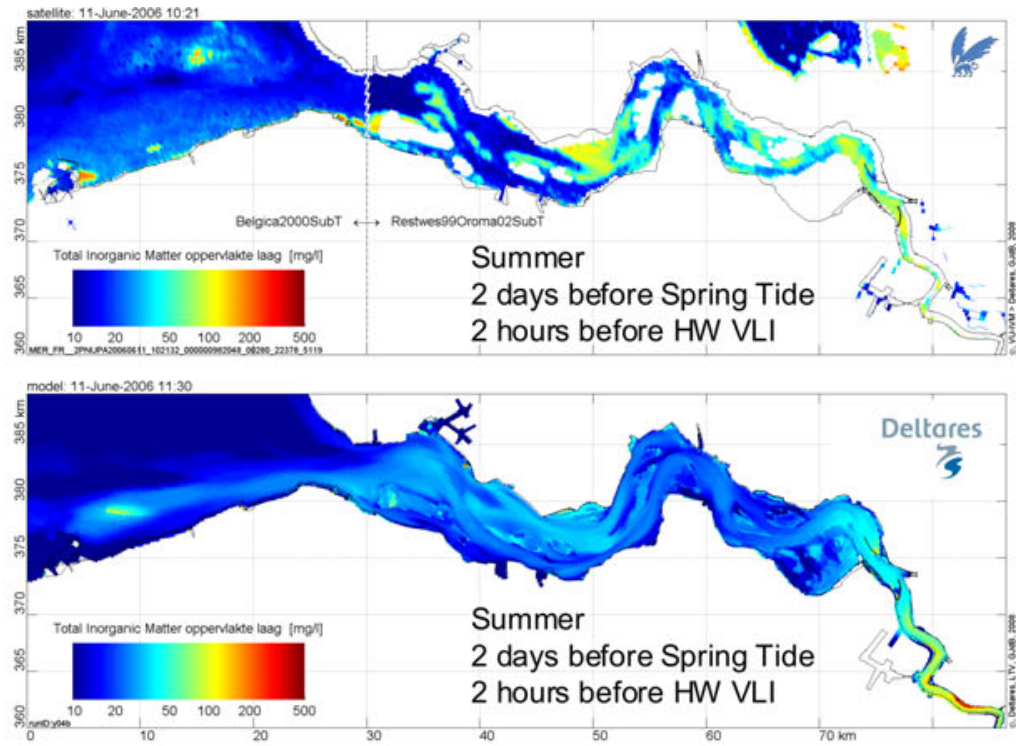

(b)
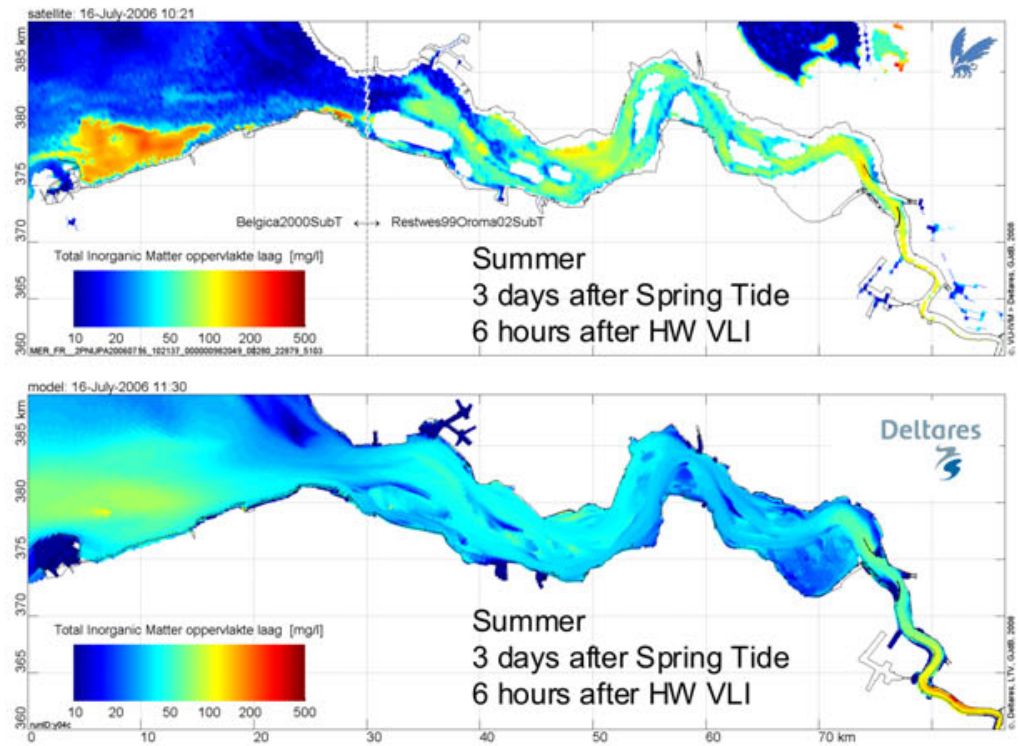

(c)
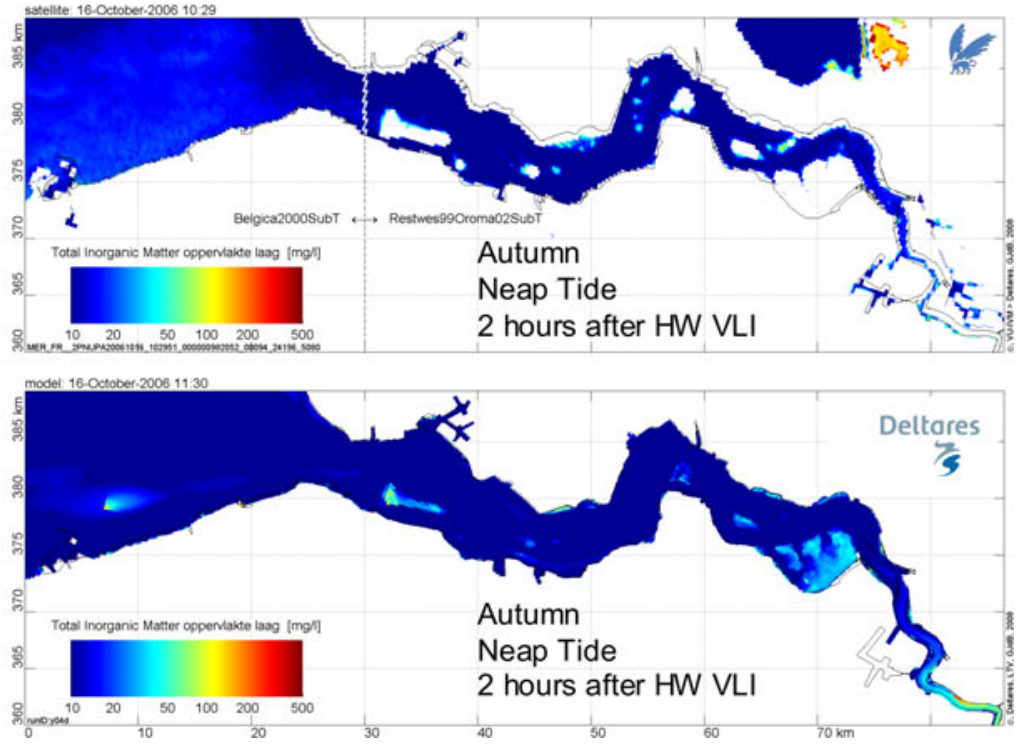

五 Springer 
(Eleveld et al. 2008), mouth of the Westerschelde and Vlaamse Banken (Fettweis and van den Eynde 2003) and Zeeschelde (Fettweis et al. 1998). The average seasonal (winter-summer) difference in SPM measured in situ at four (deep) channel stations at ca. $1 \mathrm{~m}$ below the surface is $28 \mathrm{mg} \mathrm{l}^{-1}$. When assuming a tidal prism of $2 \times 10^{9} \mathrm{~m}^{3}$ for the Westerschelde (Wang et al. 2002) and assuming the sediment is distributed evenly over the water column, this would equal $55 \mathrm{kton}$, i.e., less than the amount of mud that would be stored on the intertidal flats in summer. However, this amount would be substantially higher as our results from satellite and modelling show that high SPM concentrations occur especially above the shoals.

The mud transport model does reproduce the spatial distribution of mud in the estuary, both in the water column and in the bed as observed by remote sensing. Variation in SPM over the fortnightly and seasonal cycle is also reproduced reasonably well, but variations over the tidal cycle in particular are underestimated at most stations in the model.

Our model results show that the Westerschelde experienced a net export flux of 2 Mton mud over 2006, which is the difference of a gross export of 37 Mton and a gross import of 35 Mton from the North Sea, i.e., a residual flux of $6 \%$. This $2 \mathrm{Mt}$ is probably an overestimation due to the weak estuarine circulation in the model. Indeed, when the effect of estuarine circulation on mud transport is enhanced by introducing hindered deposition at the bed (resulting in a higher near-bed concentration and concurrently a higher near-bed inward net sediment flux), the ETM at Antwerp becomes more pronounced and net sediment export towards the North Sea decreases to nearly zero. Previous findings in the literature ranged from net mud import of 50$350 \mathrm{kton}$ year $^{-1}$ (van Maldegem et al. 1993; Verlaan et al. 1998) to net mud export of ca. $1 \mathrm{Mt} \mathrm{year}^{-1}$ (Fettweis and van den Eynde 2003). At present, the tentative model results seem to indicate that a higher storm frequency in winter causes more mud import into the estuary, leading to a slightly higher net export of mud in summer than in winter. Export in summer may be reduced when more mud would be seasonally stored on the tidal flats.

The model does not yet reproduce observed seasonal dynamics in bed composition of intertidal flats, whereas the seasonal dynamics in SPM are reasonably well simulated. The seasonal dynamics in SPM and bottom sediment may have several causes. A number of studies have attributed such dynamics to external causes, such as a higher marine or fluvial sediment supply in winter (e.g., Lindsay et al. 1996; Lesourd et al. 2003; Deloffre et al. 2006), of which discharge and wave-induced resuspension in the outer estuary is included in the model. Secondly, there may be internal causes. Of these factors, a variable wind stress is accounted for in the model, suggesting that this factor alone does not explain seasonal variation in bottom mud content. Indeed, inside the estuary its effect becomes small relative to tidal forcing. Frostick and McCave (1979) suggested that a seasonal transfer of mud from channel banks or channels to the intertidal zone accounted for a higher intertidal mud content in summer. This process does also not emerge from the model, even though simulated mud content in the channels is slightly lower in summer due to a lower SPM level. Another (internal) cause not considered is a change in the properties of the (suspended or deposited) sediment over the year. In the model, only the consolidation of mud (Quaresma et al. 2004; Sanford 2008) now induces a seasonal variation as mass is transferred from the fluff layer to the underlying bed during calm weather. Seasonal changes in the grain-size distribution of fines are not taken into account. In addition, flocs in the Westerschelde are generally greater in summer (Chen et al. 2005b), partly because of biological activity, and may break up in winter due to higher energy conditions; this may account for higher settling rates and deposition in summer (Dyer et al. 2000; Chang et al. 2007). Note that these variations in particle size and type might also influence the IOPs (scattering phase function and backscattering), sIOPs and water-leaving radiance reflectance and thus eventually the retrieved remotely sensed SPM concentrations. Test runs with our model show that changes in settling rate could well account for seasonal variation both in SPM and bed sediment. Flocculation can also partly account for the observed discrepancies in modelled sediment concentrations over the tidal cycle (Winterwerp 2002). Seasonal changes in the sediment bed due to biological effects are also neglected in the present model. Yet, the formation of a biofilm in spring by diatoms (Holland et al. 1974; Yallop et al. 1994) may cause a temporal increase in $\tau_{\text {crit }}$ in spring and summer by up to a factor 5 (Neumeier et al. 2006; Le Hir et al. 2007). Test runs with our model, implementing the (de)stabilising influence of benthos on mud as proposed by Borsje et al. (2008) showed that this had a significant effect on bed composition, but the amount of mud stored or released in this way was too small (at least in the model) to influence mud concentration in the water column on the scale of the whole estuary (van Kessel et al. 2007). As this contradicts our findings from both in situ and remote sensing data, modelling improvements are required. Such improvements may include using a thicker sand layer in which the mud can be stored or allowing exchange of mud from this layer and an underlying layer, as observed in situ due to, for example, bioturbation or deposition of sand on top of the mud layer (Herman et al. 2001; Andersen and Pejrup 2001).

Our results from SAR remote sensing also reveal a strong seasonal change in bed roughness, with significantly smoother surfaces in summer than in winter. This is in 
contrast with findings from sites where a smoother surface is found in winter due to reduction of biological (macrofaunal) activity (e.g., Anderson 1983), but supports observations on microphytobenthos inhibiting surface ripple migration (Friend et al. 2008). In most mud transport models, including ours, bed roughness resulting from microtopography (such as sand ripples) is held constant over time, and spatial differences in bed roughness as revealed by the remote sensing data are also not incorporated. However, a decrease in bed roughness in summer may influence the vertical structure of the flow and bottom boundary layer processes, reducing turbulence and bed shear stress (McLean 1981; Whitehouse et al. 2000; Le Hir et al. 2007). This process is especially relevant for shallow waters such as those in the intertidal zone at the moving edge of the tide (Whitehouse et al. 2000) and will induce a positive feedback loop of an increasingly higher mud content, smoother surface and lower bed shear stress. The impact of such a feedback loop could be substantial. Bifurcations could form, making the mud behaviour more chaotic.

Our observations show that sediment and bed properties change significantly over the year, but that these changes are spatially very heterogeneous. Satellite remote sensing provides independent, synoptic and sequential information on relevant physical and biological properties of the sediment (including bed roughness, bed mud content and microphytobenthos biomass) that can be incorporated (either as initial fields or consecutively in data assimilation) in cohesive sediment transport models to better account for changes in shear stress, critical erosion threshold and resuspension, thus providing a better insight in the feedback loops of estuarine mud dynamics.

\section{Conclusions}

The study places mud dynamics in a spatial context using a combination of remote sensing data, model data and corroborative in situ data of the Westerschelde estuary. Model results agree reasonably with the spatial distribution of both mud content of the bed sediment and SPM in the water column from both in situ and remote sensing measurements, suggesting that physical forcing now implemented in the model (tides, wind, waves and freshwater discharge) largely explains these patterns.

In situ, satellite and model data also reveal similar trends in SPM over different time-scales, ranging from semidiurnal, spring-neap and seasonal variation, generally with a factor 1.5 to 2, although the present model underestimates the variation in SPM over the semi-diurnal tidal cycle.

In situ measurements and remote sensing derived data also reveal that the mud content of the intertidal bed is ca. twice as high in summer as in winter. The model does not show the seasonal variation in bed sediment on the intertidal flats. Thus, the model results suggest that the observed seasonal dynamics may stem from other factors than seasonal physical forcing. A seasonal increase in settling velocity due to flocculation, a seasonal increase in critical shear stress for erosion on intertidal flats due to consolidation and the presence of diatoms and a seasonal decrease in bottom shear stress due to smoothening of the surface as detected by the satellite are probable, and not mutually exclusive, factors. Synoptic sequential information derived from satellite data (including bed roughness and microphytobenthos biomass) can be implemented in the mud transport model to improve its performance and shed further light on the mud dynamics at the estuary scale.

Acknowledgements This work was carried out within the framework of LTV-Slib (Long-term Vision Westerschelde). The European Space Agency provided ERS-SAR data within ESA Cat-1 project 5578 and MERIS-FR data within ESA Cat-1 project 4453. Rijkswaterstaat MOVE data of the sediment were kindly provided by Dick de Jong. We acknowledge Machteld Rijkeboer, Steef Peters and Reinold Pasterkamp, in collaboration with MUMM and Rijkswaterstaat MD, for databases with historic sIOPs and Reinold Pasterkamp for the HYDROPT Software library. We would also like to thank Luca van Duren, Herman Mulder and Peter Herman for the advice and Gerben de Boer and Annette Wielemaker for their help. Han Winterwerp and anonymous reviewers are thanked for useful comments to improve the manuscript. This is NIOO-KNAW publication number 4688 .

Open Access This article is distributed under the terms of the Creative Commons Attribution Noncommercial License which permits any noncommercial use, distribution, and reproduction in any medium, provided the original author(s) and source are credited.

\section{References}

Allen JRL, Duffy MJ (1998) Temporal and spatial depositional patterns in the Severn Estuary, southwestern Britain: intertidal studies at spring-neap and seasonal scales, 1991-1993. Mar Geol 146:147-171

Andersen TJ, Pejrup M (2001) Suspended sediment transport on a temperate, microtidal mudflat, the Danish Wadden Sea. Mar Geol 173:69-85

Andersen TJ, Mikkelsen OA, Møller AL, Pejrup M (2000) Deposition and mixing depths on some European intertidal mudflats based on ${ }^{210} \mathrm{~Pb}$ and ${ }^{137} \mathrm{Cs}$ activities. Cont Shelf Res 20:1569-1591

Anderson FE (1983) The northern muddy intertidal: seasonal factors controlling erosion and deposition-a review. Can Fish Aquat Sci 40:143-159

Baeyens W, van Eck B, Lambert C, Wollast R, Goeyens K (1998) General description of the Scheldt estuary. Hydrobiologia 366:1-14

Bale AJ, Tocher MD, Weaver R, Hudson SJ, Aiken J (1994) Laboratory measurements of spectral properties of estuarine suspended particles. Neth J Aquat Ecol 28:237-244

Booij N, Ris RC, Holthuijsen LH (1999) A third-generation wave model for coastal regions 1 . Model description and validation. J Geophys Res (Oceans) 104(C4):7649-7666

Borsje BW, de Vries MB, Hulscher SJMH, de Boer GJ (2008) Modeling large-scale cohesive sediment transport affected by 
small-scale biological activity. Estuar Coast Shelf Sci 78:468480. doi:10.1016/j.ecss.2008.01.009

Cancino L, Neves R (1994) 3D-numerical modelling of cohesive suspended sediment in the Western Scheldt estuary (the Netherlands). Neth J Aquat Ecol 28:337-345

Chang TS, Flemming BW, Bartholomä A (2007) Distinction between sortable silts and aggregated particles in muddy intertidal sediments of the East Frisian Wadden Sea, southern North Sea. Sedim Geol 202:453-463. doi:10.1016/j.sedgeo.2007.03.009

Chen MS, Wartel S, van Eck B, van Maldegem D (2005a) Suspended matter in the Scheldt estuary. Hydrobiologia 540:79-104. doi:10.1007/s10750-004-7122-y

Chen MS, Wartel S, Temmerman S (2005b) Seasonal variation of the floc characteristics on tidal flats, the Scheldt estuary. Hydrobiologia 540:181-195. doi:10.1007/s10750-004-7143-6

Deloffre J, Lesueur R, Verney R, Lesourd S, Cuvillez A, Taylor J (2006) Controlling factors of rhythmic sedimentation processes on an intertidal estuarine mudflat - role of the turbidity maximum in the microtidal Seine estuary, France. Mar Geol 235:151164. doi:10.1016/j.margeo.2006.10.011

Doerffer R, Schiller H (2007) The MERIS case 2 water algorithm. Int J Remote Sens 28:517-535. doi:10.1109/TGRS.2005.848410

Doxaran D, Froidefond J-M, Castaing P, Babin M (2009) Dynamics of the turbidity maximum zone in a macrotidal estuary (the Gironde, France): observations from field and MODIS satellite data. Estuar Coast Shelf Sci 81:321-322. doi:10.1016/j. ecss.2008.11.013

Dyer KR, Christie MC, Feates N, Fennessy MJ, Pejrup M, van der Lee W (2000) An investigation into processes influencing the morphodynamocs of an intertidal mudflat, the Dollard Estuary, The Netherlands: I. hydrodynamics and suspended sediment. Estuar Coast Shelf Sci 50:607-625

Eleveld MA, Pasterkamp R, van der Woerd HJ, Pietrzak JD (2008) Remotely sensed seasonality in the spatial distribution of sea-surface suspended particulate matter in the southern North Sea. Estuar Coast Shelf Sci 80:103-113. doi:10.1016/j.ecss.2008.07.015

ESA (2006) MERIS Product handbook. Available via http://envisat. esa.int/handbooks/meris/. Accessed 30 Jan 2009.

Fettweis M, van den Eynde D (2003) The mud deposits and the high turbidity in the Belgian-Dutch coastal zone, southern bight of the North Sea. Cont Shelf Res 23:669-691. doi:10.1016/S0278-4343 (03)00027-X

Fettweis M, Sas M, Monbaliu J (1998) Seasonal, neap-spring and tidal variation of cohesive sediment concentration in the Scheldt estuary, Belgium. Estuar Coast Shelf Sci 47:21-36

Forget P, Ouillon S, Lahet F, Broche P (1999) Inversion of reflectance spectra of nonchlorophyllous turbid coastal waters. Rem Sens Env 68:264-272

Friend PL, Lucas CH, Holligan PM, Collins MB (2008) Microalgal mediation of ripple mobility. Geobiology 6:70-82. doi:10.1111/ j.1472-4669.2007.00108.x

Frostick LE, McCave IN (1979) Seasonal shifts of sediment within an estuary mediated by algal growth. Estuar Coast Mar Sci 9:569576

Fung AK, Li Z, Chen KS (1992) Backscattering from a randomly rough dielectric surface. IEEE Trans Geosci Rem Sens 30:356-369

Grabemann I, Krause G (1989) Transport processes of suspended matter derived from time series in a tidal estuary. J Geophys Res (Oceans) 94(C10):14373-14379

Heip CHR, Goosen NK, Herman PMJ, Kromkamp J, Middelburg JJ Soetaert K (1995) Production and consumption of biological particles in temperate tidal estuaries. Oceanogr Mar Biol Annu Rev 33:1-150

Herman PMJ, Middelburg JJ, Heip CHR (2001) Benthic community structure and sediment processes on an intertidal flat: results from the ECOFLAT project. Cont Shelf Res 21:2055-2071
Herman PMJ, Middelburg JJ, van de Koppel J, Heip CHR (1999) Ecology of estuarine macrobenthos. Adv Ecol Res 29:195240

Holland AF, Zingmark RG, Dean JM (1974) Quantitative evidence concerning the stabilization of sediments by marine benthic diatoms. Mar Biol 27:191-196

Laur H, Bally P, Meadows P, Sanchez J, Schaettler B, Lopinto E, Esteban D (2002) ERS SAR Calibration. Derivation of the Backscattering Coefficient $\sigma^{0}$ in ESA ERS SAR PRI Products. Document ES-TN-RS-PM-HL09. ESA. Available via http://earth. esa.int/ESC2/. Accessed 30 Jan 2009.

Le Hir P, Monbet Y, Orvain F (2007) Sediment erodability in sediment transport modelling: can we account for biota effects? Cont Shelf Res 27:1116-1142. doi:10.1016/j.csr.2005.11.016

Le Hir P, Roberts W, Cazaillet O, Christie M, Bassoullet P, Bacher C (2000) Characterization of intertidal flat hydrodynamics. Cont Shelf Res 20:1433-1459

Le Normant C (2000) Three-dimensional modelling of cohesive sediment transport in the Loire estuary. Hydrolog Proc 14:2231-2243

Lesourd S, Lesueur P, Brun-Cottan JC, Garnaud S, Poupinet N (2003) Seasonal variations in the characteristics of superficial sediments in a macrotidal estuary (the Seine inlet, France). Estuar Coast Shelf Sci 58:3-16. doi:10.1016/S0272-7714(02)00340-2

Lindsay P, Balls PW, West JR (1996) Influence of tidal range and river discharge on suspended particle matter fluxes in the Forth estuary (Scotland). Estuar Coast Shelf Sci 42:63-82

Lumborg U, Windelin A (2003) Hydrography and cohesive sediment modelling: application to the Rømø Dyb tidal area. J Mar Syst 38:287-303

McLean SR (1981) The role of non-uniform roughness in the formation of sand ribbons. Mar Geol 42:49-74

Miller RL, McKee BA (2004) Using MODIS Terra $250 \mathrm{~m}$ imagery to map concentrations of total suspended matter in coastal waters. Remote Sens Env 93:259-266. doi:10.1016/j.rse.2004.07.012

Mobley CD, Sundman LK (2001) Hydrolight 4.2: Technical documentation. Sequoia Scientific, Redmond. Available via http:// www.sequoiasci.com/products/Hydrolight.aspx. Accessed 30 Jan 2009.

Moore GF, Aiken J, Lavender SJ (1999) The atmospheric correction of water colour and the quantitative retrieval of suspended particulate matter in Case II waters: application to MERIS. Int J Remote Sens 20:1713-1733

Moreira F (1999) On the use by birds of intertidal areas of the Tagus estuary: implications for management. Aquat Ecol 33:301-309

MUMM (2009) Harmonic tides predictor for Ostend. Available via http://www.mumm.ac.be/EN/Models/Operational/Tides/predictor. php. Accessed 30 Jan 2009.

Neumeier U, Lucas C, Collins M (2006) Erodibility and erosion patterns of mudflat sediments investigated using an annular flume. Aquat Ecol 40:543-554. doi:10.1007/s10452-0040189-8

O’Brien DJ, Whitehouse RJS, Cramps A (2000) The cyclic development of a macrotidal mudflat on varying timescales. Cont Shelf Res 20:1593-1619

Quaresma VD, Amos CL, Flindt M (2004) The influences of biological activity and consolidation time on laboratory cohesive beds. J Sedim Res 74:184-190

Rainey MP, Tyler AN, Gilvear DJ, Bryant RG, McDonald P (2003) Mapping intertidal estuarine sediment grain size distributions through airborne remote sensing. Remote Sens Env 86:480-490. doi:10.1016/S0034-4257(03)00126-3

Ridderinkhof H, van de Ham R, van der Lee W (2000) Temporal variation in concentration and transport of suspended sediment in a channel-flat system in the Ems-Dollard estuary. Cont Shelf Res 20:1479-1493 
Ridgway J, Shimmield G (2002) Estuaries as repositories of historical contamination and their impact on shelf seas. Estuar Coast Shelf Sci 55:903-928

Rijkswaterstaat (2006) Monitoring van de effecten van de verruiming 48'/43'. MOVE Report RIKZ/2007.003.

Rijkswaterstaat (2009) Waterbase. Available via http://www.water base.nl. Accessed 30 Jan 2009.

Robinson MC, Morris KP, Dyer KR (1998) Deriving fluxes of suspended particulate matter in the Humber estuary, UK, using airborne remote sensing. Mar Poll Bull 37:155-163

Royal Netherlands Meteorological Institute (2009) Weather data. Available via http://www.knmi.nl. Accessed 30 Jan 2009.

Sanford LP (2008) Modeling a dynamically varying mixed sediment bed with erosion, deposition, bioturbation, consolidation, and armoring. Comp \& Geosci 34:1263-1283. doi:10.1016/j. cageo.2008.02.011

Santer R, Schmechtig C (2000) Adjacency effects on water surfaces: primary scattering approximation and sensitivity study. Appl Optics 39:361-275

Schroeder T, Schaale M, Fisher J (2007) Retrieval of atmospheric and oceanic properties from MERIS measurements: a new Case-2 water processor for BEAM. Int J Remote Sens 28:5627-5632. doi:10.1080/01431160701601774

Schwartz R, Kozerski HP (2004) Entry and deposits of suspended particulate matter in groyne fields of the Middle Elbe and its ecological relevance. Acta Hydrochim Hydrobiol 31:391-399. doi:10.1002/aheh.200300496

Smith SD, Banke EG (1975) Variation of the sea surface drag coefficient with wind speed. Quart J Roy Meteorol Soc 101:665-673

Stelling GS, van Kester JATM (1994) On the approximation of horizontal gradients in sigma co-ordinates for bathymetry with steep bottom slopes. Int J Numerical Meth Fluids 18:915-935

Storm C, van Maldegem DC (1997) De Scheldebodem in 1992/1993: resultaten van een bodembemonstering vanaf de Scheldemonding tot aan Rupelmonde Report RIKZ AB-97.843x. Rijkswaterstaat, Middelburg.

Teisson C (1991) Cohesive suspended sediment transport: feasibility and limitations of numerical modelling. J Hydraulic Res 29:755-769

Temmerman S, Govers G, Wartel S, Meire P (2004) Modelling estuarine variations in tidal marsh sedimentation: response to changing sea level and suspended sediment concentrations. Mar Geol 212:1-19. doi:10.1016/j.margeo.2004.10.021

Toffolon M, Vignoli G, Tubino M (2006) Relevant parameters and finite amplitude effects in estuarine hydrodynamics. J Geophys Res (Oceans) 111:C10014. doi:10.1029/2005JC003104

Uncles RJ, Lavender SJ, Stephens JA (2001) Remotely sensed observations of the turbidity maximum in the highly turbid Humber estuary, UK. Estuaries 24:745-755

Underwood GJC, Paterson DM (1993) Seasonal changes in diatom biomass, sediment stability and biogenic stabilization in the Severn Estuary. J Mar Biol Assoc UK 73:871-887

van der Wal D, Herman PMJ (2007) Regression-based synergy of optical, shortwave infrared and microwave remote sensing for monitoring the grain-size of intertidal sediments. Remote Sens Env 111:89-106. doi:10.1016/j.rse.2007.03.019

van der Wal D, Herman PMJ, Wielemaker-van den Dool A (2005) Characterisation of surface roughness and sediment texture of intertidal flats using ERS SAR imagery. Remote Sens Env 98:96-109. doi:10.1016/j.rse.2005.06.004

van der Wal D, Herman PMJ, Forster RM, Ysebaert T, Rossi F, Knaeps E, Plancke YMG, Ides SJ (2008) Distribution and dynamics of intertidal macrobenthos predicted from remote sensing: response to microphytobenthos and environment. Mar Ecol Prog Ser 367:57-72. doi:10.3354/meps07535

van der Woerd HJ, Pasterkamp R (2008) HYDROPT: A fast and flexible method to retrieve chlorophyll-a from multispectral satellite observations of optically complex coastal waters. Remote Sens Env 112:1795-1807. doi:10.1016/j.rse.2007.09.001

van Kessel T, Vanlede J, Bruens A (2006) Development of a mud transport model for the Scheldt estuary in the framework of LTV. Report Z4210 WL | Delft Hydraulics and Flanders Hydraulics Research, Delft.

van Kessel T, Vanlede J, Kuijper K, de Kok J (2007) Further development and first application of a mud transport model for the Scheldt estuary in the framework of LTV. Report Z4375. WL | Delft Hydraulics and Flanders Hydraulics Research, Delft.

van Maldegem D, Mulder HPJ, Langerak A (1993) A cohesive sediment balance for the Scheldt estuary. Neth $\mathrm{J}$ Aquat Ecol $27: 247-256$

van Rijn LC (1984) Sediment pick-up functions. J Hydraulic Eng 110:1484-1502

Verlaan PAJ (2000) Marine vs. fluvial bed mud in the Scheldt estuary. Estuar Coast Shelf Sci 50:627-638

Verlaan PAJ, Donze M, Kuik P (1998) Marine vs. fluvial suspended matter in the Scheldt estuary. Estuar Coast Shelf Sci 46:873-883

Waeles B, Le Hir P, Delsinne PL (2007) Modelling sand/mud transport and morphodynamics in the Seine river mouth (France): an attempt using a process-based approach. Hydrobiologia 588:69-82. doi:10.1007/s10750-007-0653-2

Wang ZB, Jeuken MCJL, Gerritsen H, de Vriend HJ, Kornman BA (2002) Morphology and asymmetry of the vertical tide in the Westerschelde estuary. Cont Shelf Res 22:2599-2609

Whitehouse RJS, Bassoullet P, Dyer KR, Mitchener HJ, Roberts W (2000) The influence of bedforms on flow and sediment transport over intertidal mudflats. Cont Shelf Res 20:1099-1124

Widdows J, Blauw A, Heip CHR, Herman PMJ, Lucas $\mathrm{CH}$, Middelburg JJ, Schmidt S, Brinsley MD, Twisk F, Verbeek H (2004) Role of physical and biological processes in sediment dynamics of a tidal flat in Westerschelde Estuary, SW Netherlands. Mar Ecol Prog Ser 274:41-56

Winterwerp JC (2002) On the flocculation and settling velocity of estuarine mud. Cont Shelf Res 22:1339-1360

Winterwerp JC, van Kesteren WGM (2004) Introduction to the physics of cohesive sediment in the marine environment. Developments in Sedimentology 56. Elsevier, Amsterdam

Yallop ML, de Winder B, Paterson DM, Stal LJ (1994) Comparative structure, primary production and biogenic stabilization of cohesive and noncohesive marine-sediments inhabited by microphytobenthos. Estuar Coast Shelf Sci 39:565-582

Yates MG, Jones AR, McGrorty S, Goss-Custard JD (1993) The use of satellite imagery to determine the distribution of intertidal surface sediments of the Wash, England. Estuar Coast Shelf Sci $36: 333-344$ 